\title{
Knowledge Acquisition Strategies and Company Performance in Young High Technology Companies
}

\author{
Martin Friesl \\ Centre for Strategic Management, Lancaster University Management School, Lancaster University, Lancaster \\ LA1 4YX, UK \\ Email: m.friesl@lancaster.ac.uk
}

\begin{abstract}
Research on knowledge strategies argues that the configuration of activities used by companies to acquire new and leverage existing knowledge is an important influencing factor of company performance. However, we do not know very much about how companies actually structure knowledge acquisition. In addition, we do not know which configurations of knowledge acquisition are conducive to company performance. Furthermore, knowledge strategies have largely been neglected in the context of young and entrepreneurial companies. Drawing on an explorative analysis of quantitative and qualitative data, we investigate strategies and activities for knowledge acquisition in the context of young biotechnology companies in Germany. The study reveals four distinct knowledge acquisition strategies (low key, mid range, focus and explorer) and shows that these strategies differ in their relation to company performance as a result of their configuration of knowledge acquisition activities and the type of knowledge acquired.
\end{abstract}

\section{Introduction}

The knowledge-based view of the firm (Ambrosini and Bowman, 2001; Felin and Hesterly, 2007; Grant, 1996; Kogut and Zander, 1992; Spender and Grant, 1996) argues that knowledge and expertise are major influencing factors of competitive advantage. While this has been stressed with regard to well-established organizations (e.g. Bogner and Bansal, 2007), research on young companies increasingly highlights the importance of knowledge acquisition to ensure company survival (Chandler and Lyon, 2009; Christman

\footnotetext{
Thanks to Julia Balogun, Alan Gilchrist, Gerry Johnson, Winston Kwon, Joanne Larty, Stefanos Mouzas and Markus Vanharanta at Lancaster University Management School for their helpful comments on earlier versions of the paper. Also, earlier drafts were presented at the ICCM conference in Vienna and the SKM conference in Marburg. Great thanks to Sonja A. Sackmann at Universität der Bundeswehr München for her invaluable guidance in the research process.
}

and McMullan, 2004; McKelvie and Davidsson, 2009). More specifically, research on knowledge strategies indicates that a company's configuration of knowledge-oriented activities is an important driver of superior performance (Bierly and Daly, 2007; Eisenhardt and Santos, 2002; Un and Cuervo-Cazurra, 2004). In this respect, prior research has considered different types of configurations ranging from internal versus external learning and learning speed versus depth (Bierly and Chakrabarti, 1996) or the balancing of explorative versus exploitative learning (Bierly and Daly, 2007; March, 1991).

However, despite the advances in recent research, we do not know much about how young companies configure knowledge acquisition and why specific configurations of knowledge acquisition are more or less conducive to company performance (Eisenhardt and Santos, 2002; Volberda, Foss and Lyles, 2010). Bierly and Daly (2007) also criticize the lack of studies on small and medium sized enterprises although the 
extant literature has long underlined the challenges and needs of these companies (e.g. Aldrich and Auster, 1986). The purpose of this paper is to contribute to the literature on knowledge strategies in young companies by delineating the relationship of activity configurations for knowledge acquisition and company performance. Drawing on empirical data from the biotechnology industry, the paper identifies four knowledge acquisition strategies that differ in their relation to company performance and in the type of knowledge to which they provide access.

The biotechnology industry was chosen as a context. The analysis is based on a research design that combines both inductive-qualitative and deductive-quantitative research methods. Activities for knowledge acquisition and performance criteria are identified using interview data from CEOs and several industry experts. This provides the basis for a quantitative analysis in order to identify different configurations of knowledge acquisition (knowledge acquisition strategies) and their relationship to company performance.

The paper makes four contributions to existing research on knowledge strategies. First, Sammarra and Biggiero (2008) as well as Hibbert and Huxham (2005) argue that collaborations provide companies with the opportunity to acquire technological and managerial knowledge. This paper adds to these findings by showing that not only collaborations but various activities for knowledge acquisition differ in their access to technological, strategic, product development and functional knowledge. Second, this enhances our understanding of the relationship between activities of knowledge acquisition and company performance (Haas and Hansen, 2007). Based on Buckley et al.'s (2009) conceptual distinction of complementary and supplementary knowledge, we show that knowledge regarding product development and functional areas tends to be supplementary, whereas strategic knowledge and technological knowledge complement the knowledge base of young biotechnology companies. This is an important finding in order to further analyse the performance implications of knowledge acquisition strategies. Third, and based on that, the paper contributes to the literature on knowledge strategies (Bierly and Chakrabarti, 1996; Eisenhardt and Santos, 2002) by showing that the configuration of knowledge acquisition (a company's knowledge acquisition strategy) has an effect on company performance. The analysis reveals four knowledge strategies: low key, mid range, focus and explorer. While companies with low key strategies for knowledge acquisition show low (and below average) levels of company performance, focus and explorer strategies are related to above average performance. Finally, the findings presented provide more specificity to extant literature on knowledge acquisition (Christman and McMullan, 2004; West and Noel, 2009) by showing that the performance impact of knowledge acquisition strategies depends on the combination of complementary and supplementary knowledge in order to leverage the existing knowledge base, close knowledge gaps and develop new capabilities (Buckley et al., 2009).

The following section develops the conceptual basis for the analysis especially with regard to the configuration perspective applied and the existing research on knowledge strategies, after which the explorative research methodology and the context of the study are outlined in greater detail. Based on that, the findings of the quantitative and qualitative data analysis are presented, following the logic and sequence explained in the research design (see Figure 1, later). The results are then discussed in the light of recent research. The paper concludes with a summary of major findings, suggestions for future research, implications for management practice and a discussion of limitations.

\section{Knowledge acquisition strategies and company performance: a configuration perspective}

Young companies face the challenge of establishing 'a company' whilst simultaneously working on products and bringing them to market (Baker, Miner and Eesley, 2003). Young technology companies are usually based on a core of expertise in one area (e.g. a specific technology) but have deficiencies in others (Bergmann Lichtenstein and Brush, 2001). Indeed, research shows that young company performance and survival are dependent on new knowledge acquisition in order to close existing knowledge gaps (Christman and McMullan, 2004; Deeds, DeCarolis and Coombs, 2000; West and Noel, 2009). Knowledge acquisition is a key phenomenon in 
Phase1: Collection and analysis of qualitative data

- Identification of activities for knowledge acquisition

- Identification of performance criteria

Phase 2: Collection of data on knowledge acquisition

- Questionnaire

- Coding of knowledge types from

interview data

- Joint analysis of knowledge

acquisition categories and knowledge

types

Phase 3: Knowledge strategies and performance

- Cluster analysis of sample

- Quantitative data analysis of company performance

- Qualitative data analysis on

knowledge categories

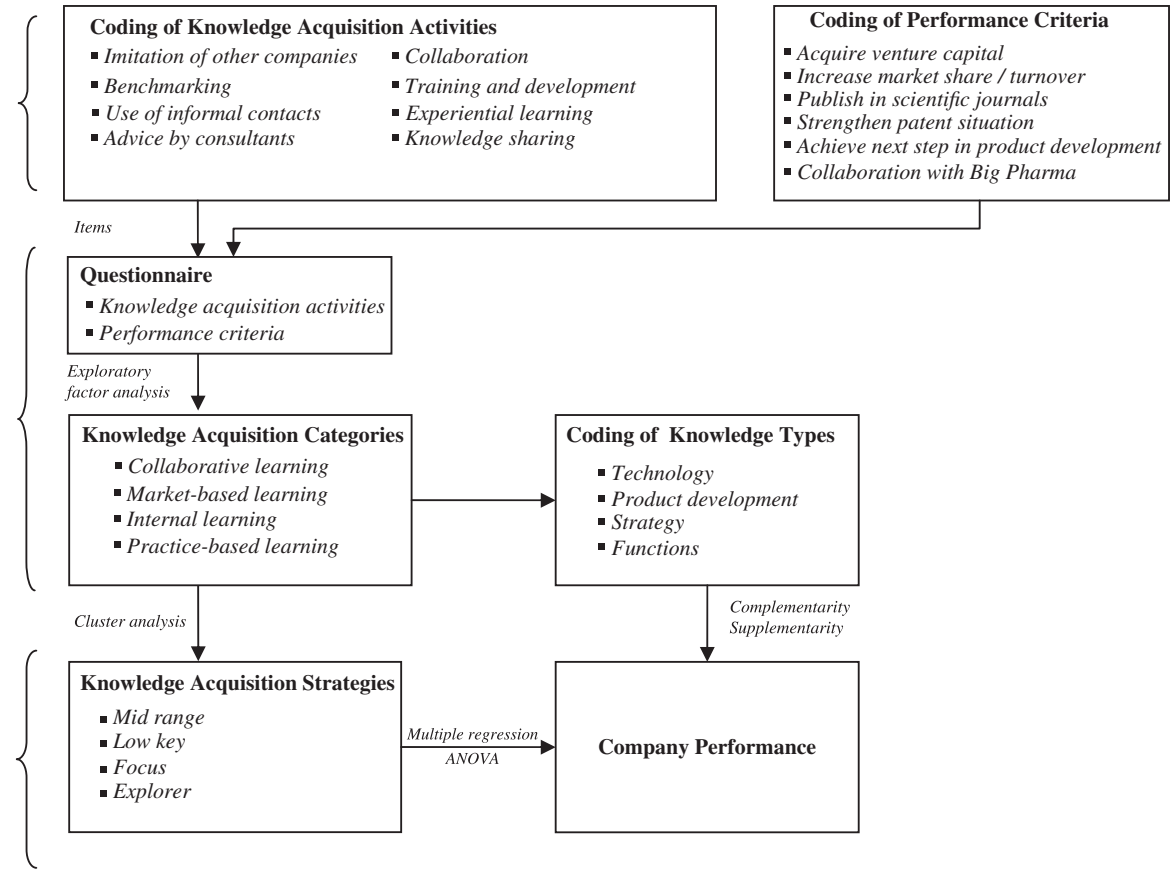

Figure 1. Research process and key concepts developed in each phase

several debates in the management literature, particularly in the literatures on organizational learning, absorptive capacity and the knowledgebased view of the firm.

The activities and processes by which companies learn and acquire new knowledge and the strategic implications for competitiveness have been a fundamental part of the literature on organizational learning (Easterby-Smith, 1997; Easterby-Smith, Crossan and Nicoline, 2000). For instance, in a conceptual paper, Huber (1991) differentiates various activities of knowledge acquisition ranging from experiential learning and hiring to vicarious learning. Recently this has been explored in a young company context. Chandler and Lyon (2009) identify a positive relationship between these activities for knowledge acquisition and company performance. Rooted in the literature on organizational learning, research on absorptive capacity investigates how firms identify, acquire and use knowledge and how this affects firms' performance and innovativeness (Cohen and Levinthal, 1990; Easterby-Smith et al., 2008; Todorova and Durisin, 2007; Zahra and George, 2002). Empirical research shows that the acquisition of new knowledge is positively facilitated by the existing stock of knowledge (Ahuja, 2000; Cohen and
Levinthal, 1990; Tsai, 2001), particularly in relation to technology and the market in which a company operates (Lichtenthaler, 2009). In a recent synthesis of the literature, Volberda, Foss and Lyles (2010) systematize several other key antecedents of a firm's absorptive capacity including individual, intra-organizational and inter-organizational factors as well as environmental conditions. The authors conclude that significant research gaps still persist with regard to the choices and actions related to knowledge acquisition and use, as well as the types of knowledge companies acquire.

There have been several attempts to systematize knowledge acquisition in the literature on the knowledge-based view of the firm. For example, De Clerq and Dimov (2008) argue that knowledge acquisition comes in two broad areas: activities related to internal and external knowledge acquisition. Hibbert and Huxham (2005), on the other hand, differentiate between knowledge transfer, where the young company learns from another party, and knowledge creation, in which the parties co-produce new knowledge. These categorizations are not mutually exclusive, but are intertwined as organizations acquire new knowledge (Hardy, Phillips and Lawrence, 2003). Research shows that young companies 
simultaneously use a plethora of different activities. Internal knowledge acquisition for example refers to organization members' experiential learning and knowledge sharing (Zollo and Winter, 2002). But knowledge acquisition might also occur through collaborations (Baum, Calabrese and Silverman, 2000; Hendry and Brown, 2006; Hibbert and Huxham, 2005; Powell, Koput and Smith-Doerr, 1996), consulting and advice from experts (Bennett and Robson, 1999), informal contacts (Cooper and Folta, 2000; Tallman et al., 2004), learning from role models (Montealegre, 2002; Oliver, 1997) or training and development activities (Branzei and Vertinski, 2006).

By focusing on activities of knowledge acquisition, we do not have the intention to reify knowledge but to acknowledge that knowledge is socially constructed by individuals in organizations as they engage in ordinary activities of organizing and communicating (Orlikowski, 2002; Tsoukas and Vladimirou, 2001). However, studying knowledge acquisition requires a decision whether to focus on activities or on the actual social practices by which knowledge gets its status (Tsoukas and Mylonopoulos, 2004). This paper focuses on activities of knowledge acquisition and the configuration of these activities. Following Bogner and Bansal (2007, p. 167) the term knowledge is used to 'indicate an outcome of any form of learning'. Activities of knowledge acquisition are representations of such forms of learning.

In order to analyse the relationship between knowledge acquisition and company performance, we take a configuration perspective (Bierly and Chakrabarti, 1996; Meyer, Tsui and Hinings, 1993). This acknowledges that companies engage in a variety of knowledge-related activities and it is the configuration of these activities that makes a difference (Bierly and Chakrabarti, 1996). In this respect prior research has investigated several types of configurations. For example, in a longitudinal study of pharmaceutical companies, Bierly and Chakrabarti (1996) identify four knowledge strategies that differ with regard to internal and external learning, radical and incremental learning, speed of learning and breadth and depth of the acquired knowledge. Their study reveals that companies with an aggressive learning strategy characterized by high levels of internal, external, radical and incremental learning and those that balance internal and external learning tend to achieve higher profit margins. Moreover, building on March (1991) research on knowledge strategies investigates the relationship of explorative and exploitative learning and its influence on company performance (Bierly and Daly, 2007; He and Wong, 2004) or strategic renewal (McNamara and Baden-Fuller, 1999). However, we still know little about why different configurations of activities for knowledge acquisition make a difference in terms of company performance.

Configuration arguments have a long legacy in organization and management research and range from organizational structure (Gresov and Drazin, 1997), the fit of activity systems (Siggelkow, 2001) to resources and capabilities (Gruber, Heinemann and Brette, 2010). Following Gruber, Heinemann and Brette (2010), a configuration perspective on knowledge acquisition provides the potential to disentangle knowledge acquisition beyond single activities (Miller, 1981) and also to understand why different configurations of activities for knowledge acquisition are equifinal, i.e. lead to similar outcomes (Fiss, 2007; Miller, 1981).

Existing research provides a mechanism to analyse the effectiveness of different knowledge acquisition strategies. Prior research focuses on the relationship of existing and new knowledge, more specifically whether the acquired knowledge is complementary (Buckley et al., 2009; Harrison et al., 2001; Song et al., 2005) or supplementary (Buckley et al., 2009) to existing knowledge. This relationship does not only determine the value of new knowledge for the company but also influences the effort it takes to integrate it in existing routines and capabilities (Cohen and Levinthal, 1990; De Clerq and Dimov, 2008; Van den Bosch, Volberda and de Boer, 1999). Following Stieglitz and Heine (2007) and Milgrom and Roberts (1995) two activities or elements are complements if doing more of activity $\mathrm{x}$ increases the (marginal) benefits of activity $y$. By the same token, activities are supplements if doing more of activity $\mathrm{x}$ does not affect the benefits of activity y. However, supplementary knowledge potentially increases a young company's scope of specialization and thus provides the opportunity to develop new organizational capabilities (Buckley et al., 2009).

Based on the premise that the complementarity or supplementarity of new knowledge affects 
performance, we set out to analyse the relationship of activity configurations for knowledge acquisition (knowledge acquisition strategies) and company performance. In the following sections these aspects are explored empirically in the context of young biotechnology companies.

\section{Methodology}

\section{Research design and context of the study}

The German biotechnology industry forms the context of this study. The biotechnology sector is widely used in research on the knowledge-based view of the firm due to its R\&D intensity, i.e. reliance on new knowledge creation (Felin and Hesterly, 2007). The German biotechnology industry is relatively young. As the industry has its origin predominantly in the BioRegio project of the German government in 1995, at the time of the study (2006) a great proportion of the biotechnology firms in Germany were younger than 11 years.

Following King and Zeithaml's (2001) and Echambadi, Campbell and Agarwal's (2006) suggestion, this study is based on a research design that combines both qualitative and quantitative methods of data collection to obtain broad knowledge on activities for knowledge acquisition and in order to develop a contextually grounded rationale to assess company performance (Shah and Corley, 2006). The research design is structured in three phases as shown in Figure 1.

\section{Phase 1: Collection and analysis of qualitative data}

The objective of this inductive phase of the research process was to develop a contextually grounded, data-driven understanding of activities for knowledge acquisition in young companies and suitable performance measures (Ketokivi and Mantere, 2010; Shah and Corley, 2006). The analysis draws upon several sources of data. First, 11 semi-structured interviews were conducted from January to May 2006 with various stakeholders knowledgeable in the biotechnology industry: young biotech companies (CEOs), venture capitalists (investment managers), a pharmaceutical company (Head R\&D), a consultant (manager, biotech industry), a research institute (scientist), a cluster organization (business development), a technology transfer service
(Head Biotechnology) and a trade association (Head Biotechnology). This wide range of different stakeholders was chosen in order to reflect the multitude of relations in which young biotechnology companies are involved (Fontana and Frey, 2005). Questions asked related to success factors of young biotechnology companies, how to measure performance and which sources interviewees thought were crucial for these companies to acquire valuable knowledge (e.g. how do young companies benefit from collaborating with you?). Four out of 11 interviewees gave their permission to record the interview. These were transcribed verbatim for subsequent data analysis. For all other interviews extensive notes were taken during the interview and were written up immediately afterwards highlighting, for example, specific words or expressions used by the interviewee (McQueen and Knussen, 2002; Yin, 2009). Second, industry reports and articles on the biotechnology sector were included in the analysis (Denzin and Lincoln, 2008). The comparison of various data sources is regularly used to increase reliability and validity of qualitative research (Maitlis, 2005; Maxwell, 1996).

The qualitative data were analysed following Miles and Huberman's (1984) categorization and theme analysis. First, longer quotes were extracted dealing with acquisition of knowledge, success factors and company performance. In a next step the quotes were assigned descriptive codes in order to develop categories of knowledge acquisition activities and performance measurement. Quotes and categories were compared across all interviewees and data sources in several iterations in order to refine categories. The analysis revealed the following categories for performance measurement in the context of young biotechnology companies.

Respondents indicate that due to the high risk that derives from the long and costly developing process of biotechnological products, the industry relies on funding by venture capitalists. Thus, the ability to secure a financing round is regarded as a success factor as it leads to financial flexibility and the possibility of hiring key employees, on both the research and the management side. Second, increasing turnover and market share is regarded as a performance indicator, though most of the companies lack significant turnover in the early years. Third, respondents indicated that publication in scien- 
tific journals is an indicator for young company success as well. Interviewees argued that the logic behind this is that it enables a company to build a reputation as being knowledgeable and proficient in a specific technological area. This helps to close deals for collaborations with pharmaceutical companies or other biotechnology companies. Fourth, a company's patent situation is regarded as an essential performance indicator. Companies usually do not hold all patents, but rely extensively on patented technologies of other companies. Securing the rights to use these technologies without the danger of patent infringement ensures the 'freedom to operate' and to pursue the intended product or service strategy. Fifth, the pharmaceutical value chain is structured in distinct phases from identifying a product candidate over pre-clinical trials to clinical trials. Financing decisions of venture capitalists as well as potential collaborations with big pharmaceutical companies depend on the development stage that companies' products are at and whether they manage to push their product through the pipeline. Finally, collaborations with big pharmaceutical companies are regarded as a performance measure. These collaborations indicate a proof of concept of the product/service a young company is about to develop and they create an early stream of income. Based on these performance criteria, items were formulated and included in the questionnaire to assess company performance.

\section{Phase 2: Collection and analysis of data on knowledge acquisition}

The objective of Phase 2 of the research process was to analyse knowledge acquisition in a broader industry sample and, drawing on qualitative data, explore which type of knowledge is acquired. Based on the qualitative-inductive data and findings of recent research a questionnaire was developed in order to assess activities in a wider industry context and analyse the linkage to company performance. In September 2006, the questionnaire was sent by email to 476 CEOs of biotechnology companies in Germany. The CEO of a young company is regarded as the most knowledgeable about the activities and sources used to acquire new knowledge (Zollo and Winter, 2002). Activities for knowledge acquisition were measured by single items, except for experiential learning $(\alpha>0.826)$, collaboration $(\alpha>0.797)$ and knowledge sharing $(\alpha=0.596)$. Reliability of multiple item measures is sufficient. For each factor an aggregated value was calculated.

By the beginning of October (the questionnaire was sent out a second time), 88 CEOs had returned the questionnaire, representing a response rate of $18.5 \%$. Following Armstrong and Overton (1977) non-response bias was assessed by comparing respondents' answers for the first and second mailings ( $\mathrm{t}$ test). The analysis did not reveal any significant differences. In order to further assess whether the sample covers the German biotechnology industry we compared our sample with databases of the Federal Ministry of Statistics (DESTATIS, 2005) and the Ministry of Research and Education (BMBF, 2006) regarding geographical location, turnover, number of employees and company age. All in all the distribution of the sample shows a good match with the German biotechnology sector (see Appendix A).

Moreover, the qualitative data were further analysed in order to identify to which types of knowledge the various activities provide access. This analysis built on the initial coding of activities for knowledge acquisition in Phase 1. Again, Miles and Huberman's (1984) categorization and theme analysis was used. Initial codes describing the type of knowledge acquired by a specific activity were assigned. In several iterations these were then grouped to bigger categories. For instance, the descriptive codes 'strengthening business model', 'avoid industry pitfalls' and 'strategic decision making' were grouped into the category 'strategy'. This additional coding of the qualitative data revealed four knowledge categories: technology (e.g. scientific results), product development (e.g. manage clinical trials, product introduction), strategy (e.g. market opportunities, pricing) and functions (e.g. finance, marketing, legal aspects etc). Additionally, we analysed whether these knowledge categories constitute supplementary knowledge (new and unrelated to existing technological knowledge base) or complementary knowledge (leverages existing technological knowledge base) in the context of young biotechnology companies. Table 2 (later) provides an overview of activities for knowledge acquisition, knowledge type, the complementary or supplementary rela- 
tion of these knowledge types and illustrative sample quotes.

\section{Phase 3: Analysis of knowledge acquisition strategies and company performance}

The objective of Phase 3 was to analyse the relationship of knowledge acquisition strategies and young company performance. Predominantly, the analysis focuses on the impact of different configurations of knowledge acquisition on performance by combining the qualitative and quantitative data analysis. Assessing company performance in the context of young biotechnology companies is challenging as most of these companies lack significant turnover and are still in the product development phase. Therefore prior research in the biotechnology sector suggests the use of self-reporting scales to assess company performance (Morgan and Berthon, 2008; Zollo, Reuer and Singh, 2002). There is a long tradition of research on performance measurement that reports high correlations between objective and subjective performance measures (Dess and Robinson, 1984; Venkatraman and Ramanujam, 1986).

Performance measurement draws on the performance criteria identified in the qualitative data (see above). Respondents were asked to rate these criteria in terms of their importance as a company objective on a five-point Likert scale. In a second step respondents indicated the degree to which the objectives were met. The values for importance and achievement were then multiplied and aggregated to calculate a performance index value (Jenner, 1999). Reliability is sufficient $(\alpha=0.705)$. Similar aggregated performance measures have been used by Morgan and Berthon (2008) and Zollo, Reuer and Singh (2002).

Following Bierly and Chakrabarti's (1996) study on knowledge strategies, Ward's hierarchical technique of clustering was used to cluster the sample companies according to different configurations of knowledge acquisition. Again, using both qualitative and quantitative data, each cluster is described according to the configuration of activities for knowledge acquisition, the type of knowledge acquired and the focus on complementary or supplementary knowledge.

The use of self-reporting scales in combination with only one data source potentially leads to common method variance (CMV). Following
Podsakoff and colleagues (2003) and Podsakoff and Organ (1986) both procedural and statistical measures were considered to control for CMV. Items measuring company performance were introduced in the context of general company objectives. The later use as a performance measure was not obvious to respondents and the item order on every survey page was randomized (Nunnally and Bernstein, 1994; Slater and Atuahene-Gima, 2004). We also statistically tested for CMV. First, Harman's one-factor test was used (Podsakoff et al., 2003). If the unrotated solution of a factor analysis of all variables points towards one single factor that explains a significant amount of the variance in the data, there is strong evidence of CMV. The exploratory factor analysis revealed eight factors with eigenvalues greater than unity that explain $70.8 \%$ of the variance. Second, Lindell and Whitney's (2001) marker variable technique was used. A marker variable was included in the survey that was considered to be theoretically unrelated to the research question. This was an item assessing respondents' professional experience. The item showed no significant correlations with predictor or dependent variables. To test whether CMV accounts for the results the marker item was included in the regression analysis as a control variable. All beta coefficients that were significant in the original analysis remained significant. None of the tests applied points towards CMV.

\section{Results}

\section{Knowledge acquisition in young technology companies}

The qualitative analysis reveals eight activities for knowledge acquisition that are predominantly important in the context of young biotechnology companies: imitation of role models (especially US biotech companies), benchmarking, use of informal contacts, advice by consultants, collaboration, training and development (including internal roles and responsibilities), experiential learning and knowledge sharing (and the respective internal support structures). For the quantitative analysis these activities for knowledge acquisition were transformed into items. Table 1 shows the descriptive statistics of the survey.

In terms of mean values, learning from experience (4.1), knowledge sharing (4.1) and 


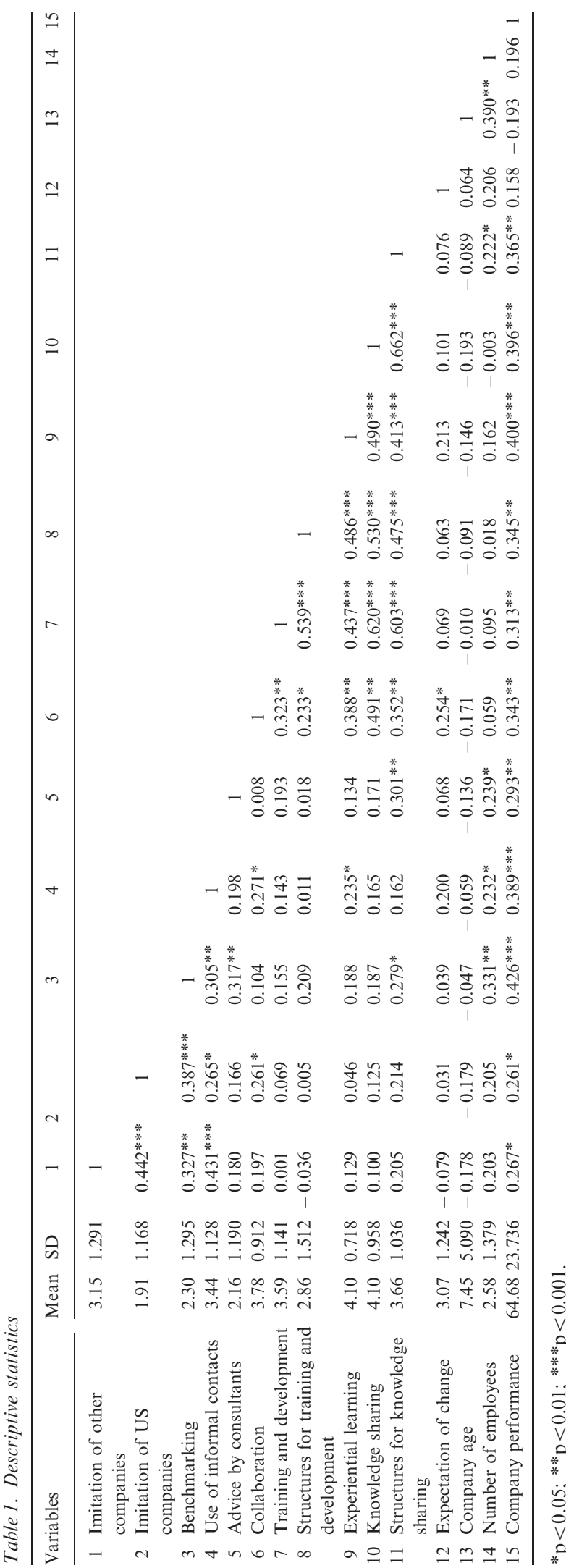

collaborations (3.8) are the most highly rated activities for knowledge acquisition. Imitation of US role models (1.91), external consultants (2.16) and benchmarking (2.3) are rated as the least important ones but have relatively high standard deviations $(>1.0)$. This indicates that subpopulations of the sample differ regarding the relative importance of these activities. Also, many activities share high correlations (e.g. use of informal contacts and imitation or knowledge sharing and training and development), indicating that activities are used simultaneously to acquire knowledge.

Based on the high correlations between activities and the assumption that activities are examples of several broader categories of knowledge acquisition, an exploratory factor analysis was applied (promax rotation) which resulted in three underlying factors of knowledge acquisition (see Appendix B). The Kaiser-Meyer-Olkin (KMO) measure of sampling adequacy (0.783) indicates that factor analysis is justified. The respective activities clearly load on a single factor, with factor loadings well above 0.6. To calculate a value for each category the underlying variables are weighted with the respective factor loadings and standardized in order to get values between 1 and 5. Collaborations do not load on one of the factors and are thus considered as a separate factor. This analysis results in four activity categories of knowledge acquisition in young biotechnology companies: collaborative learning, internal learning, market-based learning and practice-based learning. In the following sections each of these categories is explained in greater detail by drawing on both quantitative and qualitative data. Each category is characterized with regard to its sub-activities, the type of knowledge that is potentially acquired and whether this knowledge tends to be complementary or supplementary for young biotechnology companies. Table 2 provides an overview of the analysis.

Collaborative learning. As collaboration does not load on one of the resulting factors and considering its important role as an activity for knowledge acquisition as reported in extant literature (Huxham and Hibbert, 2008; Pisano, Shan and Teece, 1988; Powell, 1998), collaboration is considered a category on its own and 
Table 2. Knowledge acquisition categories, knowledge types and knowledge relation

\begin{tabular}{|c|c|c|c|c|}
\hline $\begin{array}{l}\text { Knowledge } \\
\text { acquisition }\end{array}$ & Description & $\begin{array}{c}\text { Knowledge } \\
\text { type }\end{array}$ & $\begin{array}{l}\text { Knowledge } \\
\text { relation }\end{array}$ & Sample quotes \\
\hline
\end{tabular}

categories

Collaborative - Apply and improve existing

learning

technology

- Acquire new technological

know-how

Internal

learning both technical and business
Technology

Complementary

'... we explore new methods together and the partners say, we have something extraordinary, this could be a breakthrough technology. We are then doing feasibility studies. That is, the partner, a small biotechnology company experiences a completely different work environment; they see ... different projects and new challenging applications they usually have never heard of. This leads to a tremendous improvement of their technology in breadth and depth'

Strategy Complementary '... in later phases of collaborations our partners benefit from our know-how in different therapeutic areas, e.g. oncology'

Strategy Complementary 'To imitate successful industry role models is common practice, especially in the planning and organizing in the early stages of company development. It is not exceptional that young companies change their business model two to three times, within the first two to three years...'

'We try to imitate the best in class companies (especially the US companies) in order to develop a sustainable structure in this key industry'

- Acquire knowledge in seminars related

- Roles and responsibilities for training and development

- Learn from failures and past experience

- Structures for knowledge sharing

- External advice on various topics, e.g. human resources, finance, business model etc.

- Evaluate internal processes through benchmarking learning
Technology Complementary

'[Training and development] is absolutely crucial in order to keep up with the state of the art and to recruit key employees. And to keep them, of course'

Strategy Complementary 'Analyse our competitive environment, analyse our internal conditions and be willing to really question the current position, are necessary to implement changes for the future...'

'We try to keep flat hierarchies ... this not only improves the quality of our work but also helps to share knowledge with our customers. This is crucial to spot new market opportunities'

Functions Supplementary 'I attended seminars on strategy and business development in order to acquire management knowhow'

Product Supplementary development

'In order to bring a product through the clinic a very specific expertise is necessary ... which these scientists just can't have at this point in time. These people are extraordinary researchers, but the expertise how to run clinical trials needs to be externally acquired'

Functions Supplementary 'At the beginning we ... hired a professional consultant in order to set up our marketing and sales function. This was absolutely necessary as our service is very specific and needs thorough explanation on the side of our customers'

Strategy Complementary '... we help them to find collaboration partners, in order to make deals. I think this is very ... important because these companies can't do that on their own. A lot of companies start out very promising and then get into trouble when it comes to implementation .... This is a problem of lacking know-how and awareness ... 
termed 'collaborative learning'. The qualitative data suggest that collaborative learning predominantly provides access to knowledge regarding technology and strategy. Technological knowledge refers to the experiential knowledge acquired when applying the company's technology in collaborations with pharmaceutical companies and other biotechnology companies. This includes a better understanding of a company's own technology, as well as the partner organization's approaches and methods. This knowledge is complementary to the existing knowledge base as it increases the depth of the existing technology and also broadens the scope in terms of new applications and possible technological refinements. In this respect interview respondents used terms like 'improve', 'optimize', 'broaden' or 'leverage' in order to describe the relevance of the acquired knowledge for young companies, as the following quote shows: 'These collaborations were essential in order to optimize the methods we are using, for example our protein database'. In addition, collaborative learning also provides the possibility to acquire strategic knowledge. The interview data show that, by collaborating with other companies, young biotechnology companies learn about customer expectations as well as new business opportunities, i.e. new fields of application for a given technology. Strategic knowledge is also complementary to the existing knowledge base of young technology companies as it helps to leverage their existing know-how; as one interviewee put it, 'Collaborations help us to develop market orientation, to tailor our products to the needs of our customers'.

Internal learning. 'Internal learning' comprises activities with regard to learning from experience, knowledge sharing and training and development. The qualitative data reveal that internal learning provides the opportunity for young technology companies to acquire knowledge regarding technology, strategy and functions. For example, as biotechnology is a fast paced industry, continuous training and development is necessary to remain up to date in the respective scientific area. The acquisition is also supported by knowledge sharing within the company. Interviewees described journal clubs in which the latest findings in the field are discussed and shared among team members. Internal learning supports the acquisition of strategic knowledge, e.g. in terms of 'analysing internal conditions and being willing to really question your current position', as one interviewee stated, as well as learning from prior projects. This helps to improve the overall market orientation of the company. Finally, internal learning is important to acquire functional knowledge, especially regarding finance, marketing and business development (especially through training and development). Young biotechnology companies are usually built around specific technological expertise in the pharmaceutical value chain. Thus, the acquisition of functional knowledge is supplementary in nature as it provides the opportunity to build new capabilities in functional areas like finance, marketing etc. and to close the gap regarding 'business know-how' as one respondent put it.

Market-based learning. Market-based learning comprises all activities for knowledge acquisition with regard to imitation, orientation on other companies and learning from knowledge sharing with informal contacts. In line with Morgan and Turnell (2003) the underlying factor is termed 'market-based learning'. The interview data indicate that at the heart of these activities lies the acquisition of complementary strategic knowledge about the industry, competitors, industry trends and customers. Interviewees' comments suggest that strategic knowledge supports young companies in developing a market-oriented business model. The imitation of industry role models is important for young technology companies to improve their existing business. In addition, market-based learning is important to acquire knowledge about industry trends, success factors and pitfalls; as one interviewee explained: 'It is very valuable to go back to companies that are several steps ahead in their development. These companies certainly made mistakes that they would not repeat today.'

Practice-based learning. Finally, 'practice-based learning' comprises two activities for knowledge acquisition: external advice and benchmarking. Considering that both activities provide an external view of the company with the chance to contrast existing activities with current industry practice, there is conceptual proximity 
between the two activities for knowledge acquisition. Interview data suggest that through practice-based learning young companies acquire three types of knowledge: product development, functions and strategy. The category product development summarizes knowledge on how to run clinical trials and bring products to the market. Interviewees argued that leading clinical trials according to Food and Drug Administration regulations is absolutely crucial to increase chances of product approval and reduce time to market. This expertise is highly specific and young biotechnology companies usually do not have the know-how yet to run these trials on their own. Thus, knowledge regarding product development is supplementary; it is 'knowledge these companies just can't have', as one interviewee stated. Practice-based learning also provides access to supplementary functional knowledge, especially regarding finance, marketing and legal aspects. Young companies are confronted with the challenge of becoming a 'company' while simultaneously working on product and service development, i.e. knowledge with regard to core functions like finance, marketing etc. bears efficiency potential and influences a company's ability to secure financing. While functional knowledge can be acquired via other activity categories as shown above, the involvement of external advisors (consultants, cluster organizations etc.) seems to be most appropriate. ('Consulting is necessary with regard to how to craft a business plan, how to secure a financing round ... the scientists are often overburdened.') Finally, practice-based learning seems to be crucial to acquire strategic knowledge. The interview data show that external advice helps to identify and select strategic partners and also potential investors: 'we also bring in our expertise in strategy workshops and contribute with our industry network'. Moreover, it provides the opportunity of an external evaluation of internal processes and thus creates the potential for improvement.

\section{Knowledge acquisition and young company performance}

The relationship of these categories for knowledge acquisition and company performance is analysed by multiple regression analysis (Table 3). Following West and Noel (2009), company
Table 3. Multiple regression analysis of company performance

\begin{tabular}{lcccc}
\hline Variable & Mean & SD & Model 1 & Model 2 \\
\hline Controls & & & & \\
$\quad$ Company age & 7.45 & 5.157 & $-0.233^{*}$ & -0.009 \\
$\quad$ Number of employees & $2.58^{\mathrm{a}}$ & 1.379 & $0.351^{* *}$ & 0.074 \\
Main effects & & & & \\
$\quad$ Collaborative learning & 3.78 & 0.909 & & $0.259^{*}$ \\
$\quad$ Market-based learning & 2.90 & 0.884 & & 0.117 \\
$\quad$ Internal learning & 3.64 & 0.882 & & $0.187^{+}$ \\
$\quad$ Practice-based learning 2.22 & 1.037 & & $0.314^{* *}$ \\
$\mathrm{R}^{2}$ & & & 0.114 & 0.395 \\
Adj. R & & & 0.092 & 0.343 \\
Change in $\mathrm{R}^{2}$ & & & 0.114 & 0.395 \\
$\mathrm{~F}$ & & & $5.258^{* *}$ & $7.612^{* *}$ \\
\hline
\end{tabular}

${ }^{\mathrm{a}} 10-25$ employees.

${ }^{*} \mathrm{p}<0.05 ;{ }^{*} \mathrm{p}<0.01 ;{ }^{+} \mathrm{p}<0.1$.

age and number of employees are included as control variables. Model $1 \quad\left(\mathrm{R}^{2}=0.114\right.$; $\left.\mathrm{F}=5.258^{* *}\right)$ includes only the control variables and shows that company age is significantly negatively correlated with company performance $\left(\beta=-0.233^{*}\right)$ while there is a strong positive correlation $\left(\beta=0.351^{* *}\right)$ with the number of employees. Model 2 shows the full model with the knowledge acquisition categories as explanatory variables. $\mathrm{R}^{2}$ significantly increases to 0.395 $(\mathrm{F}=7.612 * *)$. Collaborative learning $(\beta=0.259 *)$ and practice-based learning $\left(\beta=0.314^{* *}\right)$ are significant predictors of young company performance. Internal learning $\left(\beta=0.187^{+}\right)$is only weakly significant. The correlation of marketbased learning and performance is not significant $(\beta=0.117)$. The control variables are no longer significant in the full model.

The high standard deviation of some activities indicates that subpopulations of the overall sample differ in their relative rating of activities. Based on an analysis of the dendrogram and the agglomeration matrix, cluster analysis was conducted for four clusters. Table 4 compares the four clusters with regard to categories for knowledge acquisition and company performance (analysis of variance, ANOVA). Cluster analysis reveals that the configuration of categories for knowledge acquisition makes a difference with regard to company performance. Explorer and focus strategies are related to above average performance while mid range and low key strategies are related to average and below average performance, respectively. Table 4 shows the mean values for each knowledge acquisition 
Table 4. Knowledge acquisition strategies and performance

\begin{tabular}{|c|c|c|c|c|c|c|}
\hline & $\mathrm{N}$ & $\begin{array}{c}\text { Collaborative } \\
\text { learning }\end{array}$ & $\begin{array}{c}\text { Market-based } \\
\text { learning }\end{array}$ & $\begin{array}{l}\text { Internal } \\
\text { learning }\end{array}$ & $\begin{array}{c}\text { Practice-based } \\
\text { learning }\end{array}$ & Performance \\
\hline Mean & & 3.78 & 2.90 & 3.64 & 2.22 & 64.68 \\
\hline Cluster 1: Mid range & 39 & 3.88 & 3.17 & 3.40 & 2.25 & 62.92 \\
\hline Cluster 2: Low key & 12 & 2.58 & 2.08 & 2.51 & 1.17 & 40.83 \\
\hline Cluster 3: Focus & 18 & 4.15 & 2.24 & 4.55 & 1.79 & 68.56 \\
\hline Cluster 4: Explorer & 10 & 4.17 & 4.00 & 4.26 & 4.10 & 90.3 \\
\hline $\mathrm{F}$ & & 12.534 & 25.182 & 36.949 & 40.179 & 10.665 \\
\hline Significance & & 0.000 & 0.000 & 0.000 & 0.000 & 0.000 \\
\hline
\end{tabular}

category per cluster, the respective level of company performance and the overall mean values. ANOVA regarding company age and size did not result in significant mean differences between clusters. In addition, clusters are compared according CEOs' expectation of organizational change in the near future. The analysis did not reveal significant mean differences between clusters.

Mid range strategy. Companies in cluster 1 show medium mean values for all categories of knowledge acquisition (values between 3.17 and 3.88) except for practice-based learning which seemed to be of lesser importance for the companies in this cluster (2.25). Most important for this group of organizations are collaborative learning (3.88) and internal learning (3.4). Compared to the average player in the industry, these companies place more emphasis on collaborative and market-based learning, but significantly less on internal learning. This configuration of activities provides companies in cluster 1 access to a broad range of knowledge. Considering only those activity categories with medium level mean values (collaborative learning, market-based learning and internal learning), companies in this cluster predominantly acquire technological, strategic and functional knowledge (compare Table 2). Thus, except for functional knowledge which is supplementary for young biotechnology firms, this configuration of knowledge acquisition has a strong focus on complementary knowledge. This configuration of activities for knowledge acquisition results in a level of company performance that is very close to the overall sample average (62.92). Thus this configuration of knowledge acquisition is termed 'mid range strategy'.
Low key strategy. Companies in cluster 2 show fairly low mean values for all activity categories (values between 1.17 and 2.58). Also, mean values are clearly below the overall sample averages for all activity categories and particularly for practice-based learning (1.17). Although on a low level, collaborative learning (2.58) and internal learning (2.51) are most important for this group of companies. This configuration of knowledge acquisition results in a low level of company performance that is also clearly below sample average (40.83). As collaborative and internal learning are the most important means of knowledge acquisition for this group of companies (although on a low level), this configuration provides access to knowledge regarding technology, strategy and functions. Again, except for knowledge on functional areas, the dominant knowledge acquisition mode of cluster 2 is complementary.

Focus strategy. Companies in cluster 3 also focus on collaborative learning (4.15) and internal learning (4.55), but in a significantly higher range, with both cluster mean values above sample average. Market-based learning (2.24) and practice-based learning (1.79) are characterized by low mean values that are also below sample average. This configuration of knowledge acquisition results in a higher level of performance that is slightly above the overall average (68.56). Like clusters 1 and 2, the configuration of activities of companies in cluster 3 potentially allows them to acquire knowledge regarding technology, strategy and functional areas. But, the strong focus on internal learning provides young companies with the opportunity to acquire not only complementary knowledge but also supplementary knowledge, especially regarding 
functional areas like finance and marketing, as indicated by the qualitative data.

Explorer strategy. Companies in cluster 4 are characterized by high mean values for all knowledge acquisition categories with values in the range of 4.00 and 4.26. As the companies in this cluster draw on all knowledge acquisition categories on a fairly high level, this configuration is termed explorer strategy to underline the high potential for knowledge acquisition. As in clusters 1-3, collaboration (4.17) and internal learning (4.26) seem to be the most important knowledge acquisition categories. However, companies in this cluster also show high mean values for practice-based learning, which is of little importance for companies in the other clusters. This configuration of knowledge acquisition results in a high level of company performance; the performance index is clearly above sample average (90.3). As companies in this cluster draw on all categories of knowledge acquisition, they also tap into a broad portfolio of knowledge types. For example, while product development is only of minor relevance for all other clusters (due to the low mean value of practice-based learning), it is of high relevance for companies in cluster 4. Thus, in addition to the broad spectrum of complementary knowledge, companies in cluster 4 also have greater access to supplementary knowledge on functions and product development.

\section{Discussion}

In this paper we analyse the relationship between knowledge acquisition strategies and company performance for young high technology companies by linking knowledge strategies, knowledge activities and the kind of knowledge acquired in a mixed-method research design. The empirical findings reported above have several important theoretical contributions to existing research on knowledge acquisition. The following section contrasts these findings with existing research.

Young technology companies are usually characterized by an initial endowment of specialist know-how in their respective field from which they further develop their knowledge base (Bergmann Lichtenstein and Brush, 2001; Christman and McMullan, 2004). Existing research on knowledge acquisition shows that activities for knowledge acquisition are linked to different types of knowledge. While the literature on collaboration has mainly stressed technological knowledge (e.g. Vanhaverbeke, Duysters and Noorderhaven, 2002), Sammarra and Biggiero (2008) as well as Hibbert and Huxham (2005) argue that companies acquire different types of knowledge like managerial and market knowledge by engaging in inter-organizational collaboration. The findings presented in this paper add to Sammarra and Biggiero's and Hibbert and Huxham's argument. On the one hand, the data confirm their suggestion that knowledge acquisition via collaboration goes beyond technological knowledge. On the other, the findings presented in this paper significantly extend existing research by showing that also the other knowledge acquisition categories like market-based learning, internal learning and practice-based learning are related to multiple knowledge types. More specifically, these knowledge acquisition categories differ in their access to technological, strategic, product development and functional knowledge. This is an important finding, as it also provides the conceptual basis to explain why different activity categories for knowledge acquisition differ in their relationship to company performance.

Prior research indicates that new knowledge acquisition is strongly linked to company performance (Bogner and Bansal, 2007; Chandler and Lyon, 2009; Christman and McMullan, 2004; McKelvie and Davidsson, 2009) and demonstrates that this is not only a matter of simply 'more' knowledge acquisition but is dependent on the type of knowledge acquired (Haas and Hansen, 2007). In this respect Buckley et al. (2009) argue in a conceptual paper that the acquired knowledge can be complementary or supplementary in nature. This paper provides further empirical evidence. The findings presented above indicate that technological and strategic knowledge acquisition is complementary for young high technology companies as it provides the opportunity to extend and leverage companies' existing knowledge base. On the other hand, knowledge regarding product development as well as functional knowledge is supplementary in nature. It extends the knowledge base of young companies and provides the opportunity for efficiency gains (e.g. in the case of 
functional knowledge) and the establishment of new organizational capabilities (e.g. product development and introduction) (Buckley et al., 2009).

However, the data presented above also show that young technology companies do not focus on single activities for knowledge acquisition but simultaneously draw on several activity categories in order to acquire new knowledge. The realized configuration of these activity categories is a company's knowledge acquisition strategy. Cluster analysis reveals four distinct knowledge acquisition strategies that significantly differ in their configuration of knowledge acquisition and in the level of company performance: mid range, low key, focus and explorer. This understanding makes two contributions to the existing literature on knowledge acquisition and performance.

First, the findings add to the studies of Bierly and Chakrabarti (1996), Bierly and Daly (2007), Eisenhardt and Santos (2002) and West and Noel (2009) by showing that the configuration of knowledge acquisition makes a difference in company performance. It also contributes to Lichtenthaler's (2009) study which shows that learning processes in organizations can be complementary due to synergies between different types of (exploitative and explorative) learning. Eisenhardt and Santos (2002) argue that diverse configurations (portfolios in their paper) are especially valuable if the objective is to gain insights into new market and product opportunities instead of specific technical areas. This paper provides an additional explanation for the context of young companies. An explorer strategy is valuable because it both helps to leverage young companies' existing expertise and also provides the opportunity to close knowledge gaps (e.g. with regard to functional know-how like accounting and marketing). These findings also constitute a valuable addition to Bierly and Daly's (2007) assumption that there may be cases where knowledge acquisition does not improve but negatively affects the competitive position of a firm. While the data presented do not show that firm performance is negatively affected, it is still important to point out that companies sharing a low key strategy to knowledge acquisition are characterized by a below average level of performance.

Second, prior research on knowledge acquisition strategies argues that the performance impact of knowledge acquisition is limited by the lack of existing complementary knowledge resources within a firm (Tanriverdi and Venkatraman, 2005) and thus the reduced absorptive capacity of these companies (Cohen and Levinthal, 1990). The findings reported above provide further detail for this argument. Indeed, the data presented in this paper indicate that companies that realize mid range or low key strategies, those that predominantly lead to the acquisition of complementary knowledge, are characterized by average and below average performance respectively. In contrast, companies that realize focus and explorer strategies acquire both complementary and supplementary knowledge and are characterized by above average company performance. This has two implications. On the one hand it indicates that the performance impact of a young technology company's knowledge acquisition strategy depends on whether this strategy allows companies to leverage the existing knowledge base (complementary knowledge) but also on whether it closes knowledge gaps and provides the opportunity to develop new organizational capabilities (supplementary knowledge) (Buckley et al., 2009). In this respect, the findings contribute to the work of Christman and McMullan (2004) who argue that closing knowledge gaps increases new venture survival. On the other hand, and in line with Bierly and Chakrabarti (1996), the data show that the performance impact of knowledge acquisition depends on the intensity with which a specific activity category is deployed. This is interpreted as an organization's degree of engagement in activities for knowledge acquisition. While this is not explicitly shown in the data, it is assumed that the engagement could take the form of deliberate learning (Ingram, 2002; Zollo and Winter, 2002). This would imply collaborating for the sake of knowledge acquisition, but might also involve initially unintended, emergent knowledge acquisition (Huxham and Hibbert, 2008; Owen-Smith and Powell, 2004). In the latter case, intensity refers to the organization's responsiveness and willingness to react upon the opportunity to acquire new knowledge (Thorpe et al., 2005). Drawing on Grant and Baden-Fuller (2004), this might further imply that deploying activities at a low intensity may provide access to new knowledge but may not be enough to affect knowledge acquisition and learning. 


\section{Conclusion}

We have investigated the relationship between knowledge acquisition of young companies and company performance in the biotechnology industry in Germany. The analysis reveals four knowledge acquisition strategies that differ in their configuration of activities for knowledge acquisition and (as a result) in their relation to company performance. While explorer and focus strategies have a strong relation to above average company performance, mid range or low key strategies only lead to average or even below average performance, respectively. This relationship is shown both statistically and on a deeper level by combining both qualitative and quantitative data. The combined analysis reveals that the various categories for knowledge acquisition (collaborative learning, market-based learning, internal learning and practice-based learning) differ in their access to valuable complementary and supplementary knowledge. The analysis indicates that knowledge acquisition strategies that show a high intensity and that combine both complementary and supplementary knowledge acquisition are linked to higher levels of company performance.

The study is subject to several limitations. First, the small sample size affects the quality of multivariate statistical analysis. Also, the data per company stem from one respondent (the CEO) only. While the CEO of a small organization is probably the most knowledgeable respondent, this still bears the danger of biased response. Second, performance measurement exclusively relies on self-reporting scales with regard to the importance and fulfilment of company objectives because of the lack of adequate objective performance criteria. Although tests did not point towards common method bias, biases like social desirability cannot be fully ruled out. Third, as with all cross-sectional studies, the findings presented do not represent causal relations but only correlations. Fourth, the role of external consultants has been portrayed as predominantly beneficial based on the data available. However, it is acknowledged that there has been research that is critical about the role of consultants for knowledge acquisition (e.g. Clegg, Kornberger and Rhodes, 2004; Hicks, Nair and Wilderom, 2009).

Future research could further build on the notion of knowledge acquisition strategies and investigate how young companies actually orchestrate knowledge acquisition in practice. This paper provides a cross-sectional view on knowledge acquisition in an industry. Our understanding of knowledge acquisition would benefit from more detailed insights into the internal decision processes, improvisations as well as individual attitudes and sense-making activities related to different forms of knowledge acquisition. Huxham and Hibbert's (2008) paper is a good example of such an analysis in the context of learning in intra-firm collaboration. Moreover, future research could investigate how young companies' knowledge acquisition strategies are influenced by external stakeholders (e.g. chambers, trade organizations).

Practitioners also benefit from the results presented in this paper. While the findings raise awareness of the importance of knowledge acquisition for the performance of young companies, the paper also provides a detailed account of which strings to pull in order to access knowhow with regard to product development and the introduction of technological, strategic or functional knowledge. The findings suggest that knowledge acquisition in young companies is not simply about acquiring 'more' knowledge. Instead, organizations benefit from orchestrating and mindfully managing knowledge acquisition activities in order to tap into different kinds of knowledge that may help to leverage the existing technological expertise or supplement young companies' emerging knowledge base.

\section{Appendix A: Sample description}

\begin{tabular}{lcc}
\hline Variable & Sample & $\begin{array}{c}\text { Comparative } \\
\text { database }\end{array}$ \\
\hline $\begin{array}{l}\text { Turnover }^{\mathrm{a}} \\
\quad<100,000\end{array}$ & \\
$\quad 300,000-1,000,000$ & $33 \%$ & $28 \%$ \\
$\quad 1,000,000-5,000,000$ & $30 \%$ & $42 \%$ \\
$5,000,000-30,000,000$ & $8 \%$ & $7 \%$ \\
$\quad>30,000,000$ & $1 \%$ & $1 \%$ \\
Company age $^{\text {b }}$ (years) & & \\
$\quad<5$ & $36 \%$ & $36 \%$ \\
$\quad 6-10$ & $42 \%$ & $43 \%$ \\
$\quad>11$ & $18 \%$ & $21 \%$ \\
Number of employees & & \\
$\quad<5$ & $28 \%$ & $23 \%$ \\
$\quad 5-10$ & $22 \%$ & $21 \%$ \\
$11-25$ & $26 \%$ & $32 \%$
\end{tabular}


Continued

\begin{tabular}{lrr}
\hline Variable & Sample & $\begin{array}{c}\text { Comparative } \\
\text { database }\end{array}$ \\
\hline $26-50$ & $16 \%$ & $14 \%$ \\
$51-100$ & $3 \%$ & $6 \%$ \\
$>100$ & $5 \%$ & $4 \%$ \\
Geographic location & & \\
Schleswig-Holstein & $3 \%$ & $3 \%$ \\
Hamburg & $2 \%$ & $4 \%$ \\
Lower Saxony & $12 \%$ & $8 \%$ \\
Bremen & $1 \%$ & $1 \%$ \\
North Rhine-Westphalia & $12 \%$ & $11 \%$ \\
Hesse & $1 \%$ & $5 \%$ \\
Rhineland-Palatinate & $0 \%$ & $2 \%$ \\
Baden-Württemberg & $13 \%$ & $16 \%$ \\
Baviaria & $17 \%$ & $20 \%$ \\
Saarland & $0 \%$ & $1 \%$ \\
Berlin & $15 \%$ & $11 \%$ \\
Brandenburg & $4 \%$ & $6 \%$ \\
Mecklenburg-Western & $9 \%$ & $3 \%$ \\
Pomerania & & \\
Saxony & $6 \%$ & $4 \%$ \\
Saxony-Anhalt & $3 \%$ & $4 \%$ \\
Thuringia & $0 \%$ & $1 \%$ \\
\hline
\end{tabular}

${ }^{a}$ DESTATIS, 2005.

${ }^{\mathrm{b}} \mathrm{BMBF}, 2006$.

\section{Appendix B: Exploratory factor analysis of activities}

\begin{tabular}{|c|c|c|c|}
\hline Activities & $\begin{array}{l}\text { Factor } 1 \\
\text { Internal } \\
\text { learning }\end{array}$ & $\begin{array}{l}\text { Factor } 2 \\
\text { Market- } \\
\text { based } \\
\text { learning }\end{array}$ & $\begin{array}{c}\text { Factor } 3 \\
\text { Practice- } \\
\text { based } \\
\text { learning }\end{array}$ \\
\hline $\begin{array}{l}\text { Training and } \\
\text { development }\end{array}$ & 0.826 & 0.147 & 0.173 \\
\hline $\begin{array}{l}\text { Internal structures } \\
\text { for training and } \\
\text { development }\end{array}$ & 0.741 & -0.036 & 0.085 \\
\hline Experiential learning & 0.716 & 0.280 & -0.034 \\
\hline Knowledge sharing & 0.619 & 0.609 & -0.364 \\
\hline $\begin{array}{l}\text { Support structures } \\
\text { for knowledge sharing }\end{array}$ & 0.858 & 0.248 & 0.318 \\
\hline $\begin{array}{l}\text { Imitation of other } \\
\text { companies }\end{array}$ & 0.073 & 0.784 & 0.223 \\
\hline $\begin{array}{l}\text { Imitation of } \\
\text { US companies }\end{array}$ & 0.112 & 0.641 & 0.283 \\
\hline $\begin{array}{l}\text { Use of informal } \\
\text { contacts }\end{array}$ & 0.211 & 0.687 & 0.097 \\
\hline $\begin{array}{l}\text { Advice by } \\
\text { consultants }\end{array}$ & 0.196 & 0.212 & 0.782 \\
\hline Benchmarking & 0.249 & 0.418 & 0.649 \\
\hline Collaboration & 0.496 & 0.497 & -0.433 \\
\hline Cronbach's $\alpha$ & 0.834 & 0.650 & 0.479 \\
\hline
\end{tabular}

$\mathrm{KMO}=0.783 ; \chi^{2}=282.608 ; \mathrm{df}=55.000 ;$ significance 0.000 .

\section{References}

Ahuja, G. (2000). 'The duality of collaboration: inducements and opportunities in the formation of interfirm linkages', Strategic Management Journal, 21, pp. 317-343.

Aldrich, E. H. and A. A. Auster (1986). 'Even dwarfs started small: liabilities of age and size and their strategic implications'. In B. M. Staw and L. L. Cummings (eds), Research in Organizational Behavior, pp. 156-198. San Francisco, CA: JAI Press.

Ambrosini, V. and C. Bowman (2001). 'Tacit knowledge: some suggestions for operationalization', Journal of Management Studies, 38, pp. 811-829.

Armstrong, J. S. and T. S. Overton (1977). 'Estimating nonresponse bias in mail surveys', Journal of Marketing Research, 14, pp. 396-402.

Baker, T., A. S. Miner and D. T. Eesley (2003). 'Improvising firms: bricolage, account giving and improvisational competencies in the founding process', Research Policy, 32, pp. 255-276.

Baum, J. A. C., T. Calabrese and B. S. Silverman (2000). 'Don't go it alone: alliance network composition and startups' performance in Canadian biotechnology', Strategic Management Journal, 21, pp. 267-294.

Bennett, R. J. and P. J. A. Robson (1999). 'The use of external business advice by SMEs in Britain', Entrepreneurship and Regional Development, 11, pp. 155-180.

Bergmann Lichtenstein, B. M. and C. G. Brush (2001). 'How do "resource bundles" develop and change in new ventures? A dynamic model and longitudinal exploration', Entrepreneurship Theory and Practice, 25, pp. 37-58.

Bierly, P. E. I. and A. Chakrabarti (1996). 'Generic knowledge strategies in the U.S. pharmaceutical industry', Strategic Management Journal, 17, pp. 123-135.

Bierly, P. E. I. and P. S. Daly (2007). 'Alternative knowledge strategies, competitive environment, and organizational performance in small manufacturing firms', Entrepreneurship Theory and Practice, 31, pp. 493-516.

BMBF (2006). Die deutsche Biotechnologie-Branche 2006. Daten \& Fakten [The German Biotechnology Industry. Data and Facts]. Report, available at www.biotechnology.de.

Bogner, W. C. and P. Bansal (2007). 'Knowledge management as the basis of sustained high performance', Journal of Management Studies, 44, pp. 165-188.

Branzei, O. and I. Vertinski (2006). 'Strategic pathways to product innovation capabilities in SMEs', Journal of Business Venturing, 21, pp. 75-105.

Buckley, P. J., K. W. Glaister, E. Klijn and H. Tan (2009). 'Knowledge accession and knowledge acquisition in strategic alliances: the impact of supplementary and complementary dimensions', British Journal of Management, 20, pp. 598-609.

Chandler, G. N. and D. W. Lyon (2009). 'Involvement in knowledge-acquisition activities by venture team members and venture performance', Entrepreneurship Theory and Practice, 33, pp. 571-592.

Christman, J. J. and W. E. McMullan (2004). 'Outsider assistance as a knowledge resource for new venture survival', Journal of Small Business Management, 42, pp. 229-244.

Clegg, S. R., M. Kornberger and C. Rhodes (2004). 'Noise, parasites and translation', Management Learning, 35, pp. $31-44$. 
Cohen, W. M. and D. A. Levinthal (1990). 'Absorptivecapacity - a new perspective on learning and innovation', Administrative Science Quarterly, 35, pp. 128-152.

Cooper, A. and T. Folta (2000). 'Entrepreneurship and hightechnology clusters'. In D. L. Sexton and H. Landström (eds), The Blackwell Handbook of Entrepreneurship, pp. 348382. Oxford: Blackwell.

De Clerq, D. and D. Dimov (2008). 'Internal knowledge development and external knowledge access in venture capital investment performance', Journal of Management Studies, 45, pp. 585-612.

Deeds, D. L., D. DeCarolis and J. Coombs (2000). 'Dynamic capabilities and new product development in high technology ventures: an empirical analysis of new biotechnology firms', Journal of Business Venturing, 15, pp. 211-229.

Denzin, N. K. and Y. S. Lincoln (2008). 'Introduction: The discipline and practice of qualitative research'. In N. K. Denzin and Y. S. Lincoln (eds), Collecting and Interpreting Qualitative Materials, pp. 1-44. Thousand Oaks, CA: Sage.

Dess, G. G. and R. B. Robinson (1984). 'Measuring organizational performance in the absence of objective measures - the case of the privately-held firm and conglomerate business unit', Strategic Management Journal, 5, pp. 265-273.

DESTATIS (ed.) (2005). Unternehmen der Biotechnologie in Deutschland. Ergebnisse der Wiederholungsbefragung 2004. Wiesbaden. Available at www.destatis.de.

Easterby-Smith, M. (1997). 'Disciplines of organizational learning: contributions and critiques', Human Relations, 50, pp. 1085-1113.

Easterby-Smith, M., M. Crossan and D. Nicoline (2000). 'Organizational learning: debates past, present and future', Journal of Management Studies, 37, pp. 783-796.

Easterby-Smith, M., M. Graça, E. Antonacopoulou and J. Ferdinand (2008). 'Absorptive capacity: a process perspective', Management Learning, 39, pp. 483-501.

Echambadi, R., B. Campbell and R. Agarwal (2006). 'Encouraging best practice in quantitative management research: an incomplete list of opportunities', Journal of Management Studies, 43, pp. 1801-1820.

Eisenhardt, K. M. and F. M. Santos (2002). 'Knowledge-based view: a new theory of strategy'. In A. Pettigrew, H. Thomas and R. Whittington (eds), Handbook of Strategy and Management, pp. 139-164. Los Angeles, CA: Sage.

Felin, T. and W. S. Hesterly (2007). 'The knowledge-based view, nested heterogeneity, and new value creation: philosophical considerations on the locus of knowledge', Academy of Management Review, 32, pp. 195-218.

Fiss, P. C. (2007). 'A set-theoretic approach to organizational configurations', Academy of Management Review, 32, pp. 1180-1198.

Fontana, A. and J. H. Frey (2005). 'The interview - from neutral stance to political involvement'. In N. K. Denzin and Y. S. Lincoln (eds), The Sage Handbook of Qualitative Research, pp. 695-727. Thousand Oakes, CA: Sage.

Grant, R. M. (1996). 'Toward a knowledge-based theory of the firm', Strategic Management Journal, 17, pp. 109-122.

Grant, R. M. and C. Baden-Fuller (2004). 'A knowledge accessing theory of strategic alliances', Journal of Management Studies, 41, pp. 61-84.

Gresov, C. and R. Drazin (1997). 'Equifinality: functional equivalence in organization design', Academy of Management Review, 22, pp. 403-428.
Gruber, M., F. Heinemann and M. Brette (2010). 'Configurations of resources and capabilities and their performance implications: an exploratory study on technology ventures', Strategic Managmement Journal, 31, pp. 1337-1356.

Haas, M. R. and M. T. Hansen (2007). 'Different knowledge, different benefits: toward a productivity perspective on knowledge sharing in organizations', Strategic Management Journal, 28, pp. 1133-1153.

Hardy, C., N. Phillips and T. B. Lawrence (2003). 'Resources, knowledge and influence: the organizational effects of interorganizational collaboration', Journal of Management Studies, 40, pp. 321-347.

Harrison, J. S., M. A. Hitt, R. E. Hoskisson and R. D. Ireland (2001). 'Resource complementarity in business combinations: extending the logic to organizational alliances', Journal of Management, 27, pp. 679-690.

He, Z. L. and P. K. Wong (2004). 'Exploration vs. exploitation: an empirical test of the ambidexterity hypothesis', Organization Science, 15, pp. 481-494.

Hendry, C. and J. Brown (2006). 'Organizational networking in UK biotechnology clusters', British Journal of Management, 17, pp. 55-73.

Hibbert, P. and C. Huxham (2005). 'A little about the mystery: process learning as collaboration evolves', European Management Review, 2, pp. 59-69.

Hicks, J., P. Nair and C. P. M. Wilderom (2009). 'What if we shifted the basis of consulting from knowledge to knowing?', Management Learning, 40, pp. 289-310.

Huber, G. P. (1991). 'Organizational learning: the contributing processes and the literatures', Organization Science, 2, pp. $88-115$.

Huxham, C. and P. Hibbert (2008). 'Manifested attitudes: intricacies of inter-partner learning in collaboration', Journal of Management Studies, 45, pp. 502-529.

Ingram, P. (2002). 'Interorganizational learning'. In J. Baum (ed.), Blackwell Companion to Organizations, pp. 642-663. Oxford: Blackwell.

Jenner, T. (1999). Determinanten des Unternehmenserfolgs [Determinants of Company Performance]. Stuttgart: Schaeffer-Poeschel.

Ketokivi, M. and S. Mantere (2010). 'Two strategies for inductive reasoning in organization research', Academy of Management Review, 35, pp. 315-333.

King, A. W. and C. P. Zeithaml (2001). 'Competencies and firm performance: examining the causal ambiguity paradox', Strategic Management Journal, 22, pp. 75-99.

Kogut, B. and U. Zander (1992). 'Knowledge of the firm, combinative capabilities, and the replication of technology', Organization Science, 3, pp. 383-397.

Lichtenthaler, U. (2009). 'Absorptive capacity, environmental turbulence, and the complementarity of organizational learning processes', Academy of Management Journal, 52, pp. $822-846$.

Lindell, M. K. and D. J. Whitney (2001). 'Accounting for common method variance in cross-sectional research designs', Journal of Applied Psychology, 86, pp. 114-121.

Maitlis, S. (2005). 'The social processes of organizatinal sensemaking', Academy of Management Journal, 48, pp. 21-49.

March, J. G. (1991). 'Exploration and exploitation in organizational learning', Organization Science, 2, pp. 71-87. 
Maxwell, J. A. (1996). Qualitative Research Design: An Interactive Approach. Thousand Oaks, CA: Sage.

McKelvie, A. and P. Davidsson (2009). 'From resource base to dynamic capabilities: an investigation of new firms', British Journal of Management, 20, pp. 63-80.

McNamara, P. and C. Baden-Fuller (1999). 'Lesson from the Celltech case: balancing knowledge exploration and exploitation in organizational renewal', British Journal of Management, 10, pp. 291-307.

McQueen, R. and C. Knussen (2002). Research Methods for Social Science. An Introduction. Harlow: Prentice Hall.

Meyer, A. D., A. S. Tsui and C. R. Hinings (1993). 'Configurational approaches to organizational analysis', Academy of Management Journal, 36, pp. 1175-1195.

Miles, M. B. and A. M. Huberman (1984). Qualitative Data Analysis. A Sourcebook of New Methods. Beverly Hills, CA: Sage.

Milgrom, P. and J. Roberts (1995). 'Complementarities and fit: strategy, structure, and organizational change in manufacturing', Journal of Accounting and Economics, 19, pp. 179-208.

Miller, D. (1981). 'Toward a new contingency perspective: the search for organizational gestalts', Journal of Management Studies, 18, pp. 1-26.

Montealegre, R. (2002). 'A process model of capability development: lessons from the electronic commerce strategy at Bolsa de Valores de Guayaquil', Organization Science, 13, pp. 514-531.

Morgan, R. E. and P. Berthon (2008). 'Market orientation, generative learning, innovation strategy and business performance inter-relationships in bioscience firms', Journal of Management Studies, 45, pp. 1329-1353.

Morgan, R. E. and C. R. Turnell (2003). 'Market-based organizational learning and market performance gains', British Journal of Management, 14, pp. 255-274.

Nunnally, J. C. and I. H. Bernstein (1994). Psychometric Theory. New York: McGraw-Hill.

Oliver, C. (1997). 'Sustainable competitive advantage: combining institutional and resource-based views', Strategic Management Journal, 18, pp. 697-713.

Orlikowski, W. J. (2002). 'Knowing in practice: enacting a collective capability in distributed organizing', Organization Science, 13, pp. 249-273.

Owen-Smith, J. and W. W. Powell (2004). 'Knowledge networks as channels and conduits: the effects of spillovers in the Boston biotechnology community', Organization Science, 15, pp. 5-21.

Pisano, G. P., W. Shan and D. J. Teece (1988). 'Joint ventures and collaboration in the biotechnology industry'. In D. Mowery (ed.), International Collaborative Ventures in U.S. Manufacturing. Cambridge, MA: Ballinger.

Podsakoff, P. M. and D. W. Organ (1986). 'Self-reports in organizational research: problems and prospects', Journal of Management, 12, pp. 531-544.

Podsakoff, P. M., S. B. MacKenzie, J. Y. Lee and N. P. Podsakoff (2003). 'Common method biases in behavioral research: a critical review of the literature and recommended remedies', Journal of Applied Psychology, 88, pp. 879-903.

Powell, W. W. (1998). 'Learning from collaboration: knowledge and networks in the biotechnology and pharmaceutical industries', California Management Review, 40, pp. 228-240.
Powell, W. W., K. W. Koput and L. Smith-Doerr (1996). 'Interorganizational collaboration and the locus of innovation', Administrative Science Quarterly, 41, pp. 116-145.

Sammarra, A. and L. Biggiero (2008). 'Heterogeneity and specificity of inter-firm knowledge flows in innovation networks', Journal of Management Studies, 45, pp. 800-829.

Shah, S. K. and K. G. Corley (2006). 'Building better theory by bridging the quantitative-qualitative divide', Journal of Management Studies, 43, pp. 1821-1835.

Siggelkow, N. (2001). 'Change in the presence of fit: the rise, the fall, and the renaissance of Liz Claiborne', Academy of Management Journal, 44, pp. 838-857.

Slater, S. F. and K. Atuahene-Gima (2004). 'Conducting survey research in strategic management'. In D. J. Ketchen and D. D. Bergh (eds), Research Methodology in Strategic Management, pp. 227-250. Oxford: Elsevier.

Song, M., C. Droge, S. Hanvanich and R. Calantone (2005). 'Marketing and technology resource complementarity: an analysis of their interaction effect in two environmental contexts', Strategic Management Journal, 26, pp. 259-276.

Spender, J. C. and R. M. Grant (1996). 'Knowledge and the firm: overview', Strategic Management Journal, 17, pp. 5-9.

Stieglitz, N. and K. Heine (2007). 'Innovations and the role of complementarities in a strategic theory of the firm', Strategic Management Journal, 28, pp. 1-15.

Tallman, S., M. Jenkins, N. Henry and S. Pinch (2004). 'Knowledge, clusters, and competitive advantage', Academy of Management Review, 29, pp. 258-271.

Tanriverdi, H. and N. Venkatraman (2005). 'Knowledge relatedness and the performance of multibusiness firms', Strategic Management Journal, 26, pp. 97-119.

Thorpe, R., R. Holt, A. Macpherson and L. Pittaway (2005). 'Using knowledge within small and medium-sized firms: a systematic review of the evidence', International Journal of Management Reviews, 7, pp. 257-281.

Todorova, G. and B. Durisin (2007). 'Absorptive capacity: valuing a reconceptualization', Academy of Management Review, 32, pp. 774-786.

Tsai, W. (2001). 'Knowledge transfer in interorganizational networks: effects of network position, and absorptive capacity on business unit innovation and performance', Academy of Management Journal, 44, pp. 996-1004.

Tsoukas, H. and N. Mylonopoulos (2004). 'Introduction: Knowledge construction and creation in organizations', British Journal of Management, 15, pp. 1-8.

Tsoukas, H. and E. Vladimirou (2001). 'What is organizational knowledge', Journal of Management Studies, 38, pp. 973-993.

Un, C. A. and A. Cuervo-Cazurra (2004). 'Strategies for knowledge creation in firms', British Journal of Management, 15, pp. S27-S41.

Van den Bosch, F. A. J., H. W. Volberda and M. de Boer (1999). 'Coevolution of firm absorptive capacity and knowledge environment: organizational forms and combinative capabilities', Organization Science, 10, pp. 551-568.

Vanhaverbeke, W., G. Duysters and N. Noorderhaven (2002). 'External technology sourcing through alliances or acquisitions: an analysis of the application-specific integrated circuits industry', Organization Science, 13, pp. 714-733. 
Venkatraman, N. and V. Ramanujam (1986). 'Measurement of business performance in strategy research - a comparison of approaches', Academy of Management Review, 11, pp. 801-814.

Volberda, H. W., N. J. Foss and M. A. Lyles (2010). 'Absorbing the concept of absorptive capacity: how to realize its potential in the organizational field', Organization Science, 21, pp. 931-951.

West, G. P. and T. W. Noel (2009). 'The impact of knowledge resources on new venture performance', Journal of Small Business Management, 47, pp. 1-22.
Yin, R. K. (2009). Case Study Research: Design and Methods. Los Angeles, CA: Sage.

Zahra, S. A. and G. George (2002). 'Absorptive capacity: a review, reconceptualization and extension', Academy of Management Review, 27, pp. 185-203.

Zollo, M. and S. G. Winter (2002). 'Deliberate learning and the evolution of dynamic capabilities', Organization Science, 13, pp. 339-351.

Zollo, M., J. J. Reuer and H. Singh (2002). 'Interorganizational routines and performance in strategic alliances', Organization Science, 13, pp. 701-713.

Martin Friesl is a lecturer in strategic management at Lancaster University Management School. Before this he worked as a project manager for change management with Siemens IT Solutions \& Services. Martin's research interests mainly focus around the creation of knowledge and capabilities in organizations. He has had research published in the Journal of Applied Behavioral Science and the Journal of Knowledge Management. 